\title{
ЮРИДИЧЕСКИЙ АНАЛИЗ СУБЪЕКТА ТЕРРОРИСТИЧЕСКОГО ПРЕСТУПЛЕНИЯ
}

\section{НАГИЕВ Эмин - докторант кафедры Уголовного права и криминологии Бакинского Государственного Университета}

DOI 10.32782/LAW.UA.2021.4.8

В статье указъвается, что на основании уголовного законодательства Азербайджанской Республики, не подлежит уголовной ответственности лицо, которое во время совершения общественно опасного деяния (действия или бездействия) находилось в состоянии невменяемости, то есть не могло осознавать фактический характер и общественную опасность своих деяний (действий или бездействия) либо руководить ими вследствие хронического психического заболевания, временного нарушения психической деятельности, слабоумия либо иного психического заболевания.

Ключевые слова: Международнъй, законодательство, здоровъе, статья, преступление.

Существует четыре элемента, создающие содержимое преступления, одним из них является субъект преступления. Субъектом преступления является лицо, совершившее общественно опасное действие, и способное нести уголовную ответственность, соответствующую законодательству. Если выразиться точнее, субъект преступления по уголовному праву - это физическое лицо, достигшее установленного законом возраста при совершении общественно опасного деяния, предусмотренного уголовным законом, умышленно или же по неосторожности, являющийся вменяемым, а в некоторых случаях по отдельности имеющий определенные особенности, указанные в соответствующих нормах [5, с. 246-247].

В Уголовном кодексе Азербайджанской Республики не используется термин «субъект преступления». Несмотря на это, во главах Общей и Особой части уголовного закона используются другие термины, связанные с лицо, несущим уголовную ответственность. К примеру, в Общей части Уголовного Кодекса используются нижеуказанные термины:

- лицо, совершившее преступление (статьи $6,8,9,11,13)$;

- лицо, подлежащее к уголовной ответственности (статьи 7,19,20);

- осужденное лицо (статьи 49,50,51,53 и пр.);

- лицо, признанное виновным в совершении преступления (статья 58);

- лицо, отбывающее наказание (статьи 76-77).

Терминами которые используются в Особой части Уголовного Кодекса, являются нижеследующие:

- лицо, использующее свое должностное положение (статьи 154, 156, 157, 163 и пр.);

- должностное лицо (статьи 206, 308, 311 и пр.);

- другие. В юридической литературе это деление осуществил И. Агаев, и он указал на то что и в общей и в особой частях , по сути, когда речь идет о лицах, так или иначе названных, то имеются ввиду субъекты преступления [3, с. 334]. 


\section{Кримінальне право, кримінальний процес та криміналістика}

Как и было указано, субъект преступления является одним из четырех составляющих элементов преступления. Поэтому субъект преступления входит в состав преступления в качестве важного признака. В соответствии с требованием статьи 19 Уголовного кодекса Азербайджанской Pеспублики «Уголовной ответственности подлежит вменяемое физическое лицо, достигшее возраста, установленного настоящим Кодексом и совершившее преступление» [1, с. 19].

Если в деянии не имеются признаки субъекта, установленные уголовным законом, то и состава преступления тоже нет. Возраст и вменяемость являются общими признаками, являющимися важными для признания физического лица в качестве субъекта преступления. Принято называть общим субъектом, лица, сочетающее в себе эти признаки. Наряду с перечисленными признаками возрастного предела и вменяемости, принято назвать особым субъектом тот субъект, в котором имеются дополнительные признаки, необходимые для возникновения ответственности.

Преступление является социальным событием, поэтому субъектом преступления может являться человек, имеющий разум и свободу воли. Такая позиция соответствует обязанностям и принципам уголовного законодательства.

Субъектом любого преступления может быть только вменяемый человек. Вменяемость- это способность лица, совершившего общественно опасное деяние, осознать общественно опасный характер своих действий, и его способность управления ими [3, с. 340], или же осознание лицом характера своих действий, и руководство ими, в том числе, его способность отвечать за совершенное им общественно опасного деяния [2, с. 60].

В соответствии со статьей 21 Уголовного кодекса Азербайджанской Республики, не подлежит уголовной ответственности лицо, которое во время совершения общественно опасного деяния (действия или бездействия) находилось в состоянии невменяемости, то есть не могло осознавать фактический характер и общественную опасность своих деяний (действий или бездействия) либо руководить ими вследствие хронического психического заболевания, временного нарушения психической деятельности, слабоумия либо иного психического заболевания. Аицу, совершившему общественно опасное деяние (действие или бездействие) в состоянии невменяемости, судом могут быть назначены принудительные меры медицинского характера, предусмотренные настоящим Кодексом [1, с. 21].

Важным признаком субъекта преступления является возрастной предел дающий возможность привлечь к уголовной ответственности. Возрастным пределом, дающим возможность привлечения к уголовной ответственности, является возрастной предел после его достижения, лицо бывает способным действовать в соответствии со здоровым мышлением в соответствии с его психофизическим развитием, осознавать общественную опасность своих действий и их результатов.

В истории развития уголовного законодательства имеются различные подходы к возрастному пределу. В «Основных началах по Уголовному праву Азербайджанской ССР», принятых в 1920 году, субъект преступления устанавливается с 14 лет. Аица, не достигшие четырнадцатилетия при допуске каких- либо ошибок, к ним применяются меры воспитательного характера. Статья 18 УК Азербайджанской Республики. Принятого в 1922 году, сохраняет в себе положения ранее действующего законодательства, и установил возрастной предел для субъекта преступления в некоторых преступлениях 14 лет. Закон, в тоже время, смягчает срок наказания, установленного лицам с 14 по 16 лет, до половины высшей меры наказания, установленного в санкциях, а срок наказания, установленного лицам с 16 по 18 лет до одно трети части высшей меры наказания установленного в санкциях статьи 18а и 186 УК. В основных началах уголовного законодательства Союзов ССР и союзных республик, принятом в 1924 году, не было указаний о возрастном пределе субъекта преступления. В связи с тем, что в основных началах этот вопрос 
остался открытым, то начиная с 1926 года в Уголовных кодексах, принятых в республиках, возрастной предел, установленный для субъекта преступления, решался по разному. Например, во втором Уголовном Кодексе АР, принятом в 1927 году, возрастной предел для субъекта, совершившего некоторые преступления, устанавливался с 14 лет, но в Уголовном Кодекса Беларуси, субъектом преступления совершившего определенное преступление, считалось лицо, достигшее 16 лет. Затем в уголовных кодексах республики были сделаны некоторые серьезные изменения по вопросам уголовной ответственности несовершеннолетних. Әти изменения, в первую очередь, были закрыты постановлением ВРК и СНК $\mathrm{CCP}$ «O мерах борьбы с преступностью среди несовершеннолетних», от 7 апреля 1935 года.

Этим постановлением, вступившим в законную силу, в первую очередь, привлекается внимание к борьбе с преступностью среди несовершеннолетних. В тоже время, решением от 7 апреля 1935 года для субъекта преступления для некоторых преступлений, был установлен возрастной предел 12 лет. Общий возрастной предел в данном постановлении был снижен до 14 лет. После этого в Уголовных Кодексах республик были сделаны соответствующие изменения в соответствии с указаниями, связанными с возрастным пределом постановления союза.

Статьей 12 УК АР (1927 года) возрастной предел в связи с кражей. С проявлением насилия, нанесением травмы телу, убийство за преступления, становящиеся причиной железнодорожной аварии- указано 12 лет, а за прочие преступления- указано - 14 лет.

Постановлением от 7 апреля 1935 года, в том числе, из уголовных кодексов республик было снято и указ о необходимости снижения наказания несовершеннолетних до половины или же в размере одной трети наказания.

Указание, относящееся к возрастному пределу субъекта преступления УК Азербайджанской Республики от 1927 года, было применено до 6 января 1959 года до вступления в законную силу Основ уголовного законодательства Советского союза и союзных республик. В основах для субъекта преступления указано 16 лет, а в некоторых преступлениях- указано- 14 лет. Возрастной предел, установленный Основами, в дальнейшем были включены в новые уголовные кодексы, принятые в 1959-1960 гг. [5, с. 249].

При установлении возрастного предела для привлечения к ответственности учитывались уровень сознания несовершеннолетнего, его способность воспринимать события в социальной среде и действовать соответствующим образом. Умение понимать социальные опасности поведения человека постепенно формируется в процессе воспитания и в результате жизненных наблюдений. В таких советах, как, не бери чужое, не бросай камень, попадешь кому- то в глаз, остерегайся огня и не дерись, социальная опасность определенных действий постепенно прививаются в семье, школе и сообществе. Такое обучение помогает подросткам с раннего возраста понять социальную опасность действий, направленных против жизни, здоровья, собственности и общественного порядка. Когда человек достигает определенного возраста, он постепенно накапливает жизненный опыт, понимает свои действия и развивает способность выбирать правильное поведение в той или иной ситуации [5, с.249].

Уголовной ответственности подлежит лицо, достигшее ко времени совершения преступления шестнадцатилетнего возраста. Аица, достигшие ко времени совершения преступления четырнадцатилетнего возраста, подлежат уголовной ответственности за умышленное убийство, умышленное причинение тяжкого или менее тяжкого вреда здоровью, похищение человека, изнасилование, насильственные действия сексуального характера, кражу, грабеж, разбой, вымогательство, неправомерное завладение автомобилем или иным транспортным средством без цели хищения, умышленные уничтожение или повреждение имущества при отягчающих обстоятельствах, терроризм, захват заложника, хулиганство при отягчающих обстоятель- 


\section{Кримінальне право, кримінальний процес та криміналістика}

ствах, хищение либо вымогательство огнестрельного оружия, боеприпасов, взрывчатых веществ и взрывных устройств, хищение либо вымогательство наркотических средств или психотропных веществ, приведение в негодность транспортных средств или путей сообщения [1, с. 20].

Состав преступлений, наказуемых с 14 лет в действующем Уголовном кодексе, стал гораздо более конкретным. Если в предыдущем УК необходимый уровень защиты был установлен в случае умышленного убийства в состоянии сильного психического возбуждения, умышленного убийства матерью новорожденного ребенка, умышленного убийства, переходящего необходимый уровень самозащиты, убийства по неосторожности и причинения тяжких или мало тяжких преступлений, легких телесных повреждений в состоянии сильного эмоционального стресса, если ответственность за причинение тяжких телесных повреждений путем опрокидывания, причинения легких телесных повреждений, избиения, пыток была установлена в возрасте с 14 лет, действующий Уголовный кодекс определяет ответственность за эти преступления возрастной предел с 16.

В целом, если мы сравним статью 10 Уголовного кодекса 1960 года со статьей 20 действующего Уголовного кодекса, которая предусматривает перечень преступлений, наказуемых до 14 лет, мы можем сравнить количество преступлений, наказуемых до 14 лет с действующим уголовным законодательством, и становится очевидно, что их число было значительно сокращено.

В Уголовном кодексе установление увеличенного минимального возрастного предела уголовной ответственности осуществляется двумя способами:

- Путем указания соответствующего возрастного предела в диспозиции Особой части Уголовного кодекса;

- Бланкетным способом, требующих обращения прочих нормативных актов, определяющих минимальный возрастной предел субъекта преступления.

Например, в нижеуказанных составах преступления уголовная ответственность устанавливается не менее с 18 лет:
- Вовлечение несовершеннолетнего в совершение преступления (статья 170),

- Вовлечение несовершеннолетнего в занятие проституцией, либо совершение аморальных действий (статья 171),

- Уклонение от прохождения военной службы (статья 321),

- В том числе, субъект военных преступлений (XII раздел особой части УК).

Несомненно, чтобы стать капитаном корабля, врачом, должностным лицом по другим должностям, необходимо достичь совершеннолетия, вопрос возрастного предела в решении ответственности ст.ст. 142, 269, 308. 309, 311 , 313, 314 и пр. УК, связан с особыми субъектами [3, с. 350].

Как и видно из содержания статьи 20.2 Азербайджанской Республики, субъектом террористического преступления является лицо, достигшее 14-летия. Но некоторые авторы предлагают установить возрастной предел не в качестве 14 лет, а 16 лет. Ч.Мустафаев, который возражает против установления возрастного предела субъекта террора в качестве 16 лет, обосновывает свои мысли следующими изречениями: «В сравнении с предыдущими периодами, в нынешних условиях, когда сознание человека развивается очень быстро, террор и террористические акты широко распространяется, и его вредные результаты воспринимаются всеми, то невозможно принять тот факт, что лицо достигшее 14-летия не может воспринять суть данного преступления. Уже является реальностью то, что в сегодняшний день дети малой возрастной группы с помощью интернета могут осуществлять различного рода операции, и могут заполучить информации. Дети 14 лет несравненно отличаются от своих сверстников, живших в прошедшие годы. Исследования показывают, что в сравнении с прошлыми годами преступники и, в особенности, их молодая часть, более склонны к безжалостности. В таких условиях является обоснованным установление уголовной ответственности за террористический акт с 14 лет» [4, с. 39].

Раздел терроризма по определенной классификации делается предметом обсуж- 
дения. И так, некоторые авторы указывают на 2 формы терроризма:

- создание преступной организации для совершения террористического акта, не связанной с государством;

- террористический акт, совершенный одним государством против другого государства [9, с.79-80].

Внутренний терроризм совершается двумя субъектами:

- государство совершает внутреннюю террористическую деятельность против своего народа;

- допускают террористические акты против своих политических и экономических конкурентов со стороны внутренних террористических группировок внутри страны, в том числе со стороны различных лиц.

Первый вид внутреннего терроризма, т. е. террористические акты, совершаемые государством, относительно надежно контролируется международными организациями. Международные организации держат под наблюдением соблюдение прав человека и гражданина в разных странах.

Международный терроризм осуществляется и самим террористическим государством (т.е. самим государством, помогающим терроризму), и в том числе международными террористическими организациями. К таким типам террористической организации относятся «Аль-Каида», «БенАаден», «Хамас» в Палестине и Израиле, «Хизбалла» (Ливан), «Братья- мусульмане» (Египет, Сирия, Саудовская Аравия) и пр. $[6$, с. 283].

В другом источнике террористические источники делятся на три группы.

- Террористическая политика осуществляемая государствами- государственный терроризм. Накануне кризиса в зоне залива в 2003 году по данным ООН и Госдепартамента СIIA к государствам, поддерживающим терроризм, относятся Иран, Ирак, Сирия, Судан, Китай, Северная Корея, Куба и Аивия.

- Самофинансирование террористической организации. Такого рода организации используя наркобизнес, незаконную продажу оружия, торговлю людьми, за- хват в заложников, контрабанду, фальшивое денежное обращение, различного рода пожертвования и пр., относящиеся к международной преступности, приобретают огромный капитал, и используют эту прибыль в целенаправленном терроризме.

- Террористические организации, которые непосредственно не занима-ются терроризмом, но финансируют организации, группировки и пр., заинтере-сованные в совершении террористических операций [10]. Международный терроризм, как преступление отличается от обычного терроризма (терроризм, с которым ведется борьба в национальном законодательстве) высокой степенью общественной опасности. Что делает это преступление более социально опасным, так это то, что во многих случаях оно организовано государством и направлено против международных отношений, международной безопасности и других подобных объектов. Кроме того, тот факт, что государство не является живым организмом, и в этом отношении исключение его способности нести уголовную ответственность как отдельное лицо никоим образом не должны ограничивать его способность выражать уголовную ответственность за это преступление. Учитывая генезис преступлений и правонарушений, закономерности развития и влияние мер против всех форм преступности на эволюцию общества, а также опыт преследования юридических лиц, то возможно достичь определения правовых основ уголовной ответственности государства. Субъектом преступления международного терроризма является не только вопрос ответственности государства как формы политической организации правительства, но и вопрос его ответственности наряду с ответственностью конкретных физических лиц.

Государство управляется соответствующими структурами власти и должностными лицами, руководящими ими. Государство примет аморфную форму без этих учреждений, без лиц, руководящих этими учреждениями. И так, во всех случаях движущей силой являются индивидуальности [4, s.29-30]. Мы тоже принимаем мысли ав- 


\section{Кримінальне право, кримінальний процес та криміналістика}

тора, и считаем, что в любом случае субъектом преступления является физическое лицо.

В юридической литературе встречается идея, что субъектом терроризма может быть как отдельное лицо, так и устойчивое объединение отдельных лиц и террористических групп, избравших методы насилия и терроризма для достижения своих целей [8, с. 142].

В литературе встречается мысль, что существует три синдрома террористов, совершающих террористические преступления. Это нижеследующие:

- Зомби,

- Рембо,

- Камикадзе-джихад

Зомби - страшное существо. Оно совершает ужасные убийства и его невозможно убить, потому что оно уже мертво. Им присуще создавать ужас. Они жестокие люди, которые длительное время получали патологический стресс в очень тяжких стрессовых ситуациях.

Рембо - террористы таким синдромом, это люди, стремящиеся к ужасу во имя высоких целей, и не умеющие жить по другому. Им присущи такие качества как эмоциональность, честность, желание находится в очень экстремальных ситуациях. Они не могут убивать кого попало, они убивает ради важных целей. Их лозунгом является «Мы защищаем людей, подвергшихся нападению».

Камикадзе - джихад - террорист, готовый умереть по поручению. Террористы жертвуют своей жизнью, им нравится уйти в иной мир, но в тоже время по мере возможности становятся причиной смерти врагов, и должны отвести их в иной мир. Чувство камикадзе- это устранить страх, и убить в себе чувство страха. Их основной целью является умереть «за что-нибудь». Әто является подсознательным признанием самоуничтожения [7, с. 78-79; 8, c. 144].

Профессор Ф.Самандаров в следующей форме анализирует психологические особенности личности террориста:

- чувства человека, облеченного властью над высокой миссией;
- чужое отношение к положительным общественным ценностям;

- склонность к отрицательному мышлению. Человек, который видит в жизни только отрицательные стороны всего;

- склонность создавать личные проблемы за пределами источника и в то же время сосредотачиваться на защите себя вокруг «себя»; отсутствие самокритики и самовлюбленность;

- считать себя незаменимым лицом в группе, внутри террористической организации, в партии, среди народа;

- жить с желанием быть знаменитой личностью в обществе самоутверждения;

- постоянно мыслить о готовности к самозащите;

- стоять на самой низкой ступеньке терпимости, часто раздражаться. Нервозность, характерное психологическое состояние;

- жить внутри высокого стресса волнения.

Само собой ясно, что перечисленные психологические особенности не являются характерными для каждого участника террористической группы. Исследователи, работающие вокруг этой темы, показывают, что для личности террористов не характерна какая- либо психологическая патология. Кроме этого внутри террористов немало людей с нарушением психической деятельности [6, с. 290].

\section{Аитература}

1. Уголовный Кодекс Азербайджанской Республики. Баку: «Hüquq (Право)» 2017, 756 с.

2. Комментарий Уголовного Кодекса Азербайджанской Республики / под редакцией Ф.Ю.Самандарова, II часть, Баку: издание Bakı: «Hüquq (Право)», 2018, 800 с.

3. Агаев И.Б. Состав преступления. Учебник. Баку: Издательство Tәhsil nəşriyyatı, 2005, $496 \mathrm{c}$.

4. Мустафаев Ч.Ф. Терроризм (понятие, причины возникновения, предупреждение и прогнозирование), Баку, Издательство Çinar-Çap, 2005, 191 с.

5. Самандаров Ф.Ю. Уголовное право. Общая часть. Учебник. Баку: «Hüquq (Право)» 2018, 724 с. 
6. Самандаров Ф.Ю. Криминология. Учебник для Высших Учебных Заведений. Bakı: Издательство Бакинского Университета. 2018, 428 с.

7. Иванов И.Е. Психология терроризма. Предупреждение и пресечение

террористических актов. СПб.: Камея, 2005, 125 с.

8. Калинин Р.С. К вопросу о социально-психологическом аспекте феномена терроризма, Актуальные проблемы российского права. 2015. № 8 (57) август, с.141-146.

9. Крылов Н.Б., Решетов Ю.А. Государственный терроризм-угроза международной безопасности // Советское государство и право. М: Наука, 1987, № 2, с.78-84.

10. https://www.meqam.webnode.com/ meqaleler/terrorizm
Emin Naghiyer,

Doctoral student of the Department of Criminal Law and Criminology of Baku State University

\section{LEGAL ANALYSIS OF THE SUBJECT OF A CRIME OF TERRORISM}

The article indicates that on the basis of the criminal legislation of the Republic of Azerbaijan, a person who, during the commitment of a socially dangerous act (action or inaction) was in a state of insanity, that is, could not realize the actual nature and social danger of his/her actions (actions or inaction) or control them due to chronic mental illness, temporary mental impairment, dementia or other mental illness, is not subject to criminal liability.

Key words: international, legislation, health, article, crime. 